\title{
Pengaruh Kualitas Pelayanan Dan Harga Terhadap Kepuasan Serta Dampaknya Pada Loyalitas Konsumen Indomaret Bagus Kuning Plaju
}

\author{
Ilhamsyah ${ }^{1}$, Agus Mulyani ${ }^{2}$ \\ ${ }^{1}$ Manajemen, Fakultas Ekonomi, Univ. PGRI Palembang, ilhamsyah@univpgri-palembang.ac.id \\ 2Manajemen, Fakultas Ekonomi, Univ. PGRI Palembang, agusmulyani@univpgri-palembang.ac.id
}

\begin{abstract}
ABSTRAK
Tujuan penelitian untuk melihat pengaruh antara kualitas pelayanan jasa dan harga dengan kepuasan konsumen dan loyalitas konsumen sebagai variabel terikat. Populasi dihitung melalui ratarata jumlah konsumen setiap bulannya yaitu 824 sedangkan sampel menggunakan Metode Accidental Sample sebayak 90. teknik pengumpulan data adalah kuesioner dan wawancara. Dengan cara menyebar angket dan bertanya secara secara langsung kepada konsumen. Pengujian Instrumen yaitu uji validitas instrumen, uji reliabilitas. Metode analisis yaitu uji normalitas data, uji model terdiri uji heteroskedastisitas. uji multikolinieritas, Model Analisis yaitu analisis jalur yang dihitung dengan dua persamaan struktural yaitu persamaan regresi yang menunjukkan hubungan yang dihipotesiskan, uji koefisien untuk melihat tingkat signifikansi masing-masing koefisien regresi.

Hasil Penelitian terdapat pengaruh signifikan kualitas pelayanan jasa terhadap kepuasan konsumen, terdapat pengaruh signifikan harga terhadap kepuasan konsumen,terdapat pengaruh signifikan kualitas pelayanan jasa terhadap loyalitas konsumen, tidak terdapat pengaruh signifikan harga terhadap loyalitas konsumen dan tidak terdapat pengaruh signifikan kepuasan konsumen terhadap loyalitas konsumen di Indomaret Bagus Kuning Plaju.
\end{abstract}

Kata kunci : Kualitas Pelayanan, Harga, Kepuasan dan Loyalitas Konsumen

\section{PENDAHULUAN}

Dengan banyaknya bisnis ritel yang muncul maka persaingan dalam bisnis ritel semakin ketat, untuk dapat memenangkan persaingan agar tidak ditinggalkan oleh konsumen, maka pelaku bisnis harus mampu bersaing, salah satu hal yang dapat dilakukan adalah dengan mempertahankan pasar mereka melalui program pengembangan konsumen. $\mathrm{Hal}$ ini merupakan salah satu strategi untuk mempertahankan bisnis dan profit perusahaan (Sudaryono, 2016:153). Imbalan dari loyalitas sendiri bersifat jangka panjang dan komulatif jadi semakin lama seorang pelanggan loyal terhadap suatu produk atau jasa, semakin besar laba yang diperoleh perusahaan dari seorang calon konsumen (Griffin, 2015:95). maka bisnis ritel seharusnya memiliki rancangan strategi yang tepat dalam mencapai tujuan mempertahankan pelanggan atau konsumen dan membuat mereka setia. Dengan persaingan yang semakin ketat, dimana semakin banyak produsen yang terlibat dalam pemenuhan kebutuhan dan keinginan konsumen, bisnis ritel harus diletakkan faktorfaktor yang dapat mempengaruhi konsumen untuk dapat berkunjung dan membeli produk retail.

Keberhasilan

Indomaret mencapai tujuan dan sasarannya sangat di pengaruhi oleh perusahaan memasarkan produknya. Tujuan perusahaan untuk dapat menjamin kelangsungan hidupnya, berkembang dan mampu bersaing, hanya mungkin apabila perusahaan dapat menjual produknya dengan harga yang menguntungkan pada tingkat kuantitas yang diharapkan serta mampu mengatasi tantangan dari para pesaing dalam pemasaran.

Salah satu tujuan utama aktivitas pemasaran seringkali dilihat dari pencapaian loyalitas konsumen. 
Loyalitas konsumen merupakan hal terpenting pada pengulangan pembelian pada pembelian pelanggan. (Nanda, 2016:22). Melalui kepuasan konsumen produsen dapat mengukur keinginan dan kebutuhan konsumen terhadap barang yang dipasarkan. Persaingan bisnis yang kiat ketat mendorong badan usaha berlombalomba untuk memberikan pelayanan maksimal agar pelanggan merasa puas memilih perusahaan tersebut dalam pemenuhan kebutuhan. Kompetetifnya usaha ditandai dengan banyaknya perusahaan yang berusaha untuk merebut market share dan new market melalui beragam cara dan inovasi yang ditampilkan dalam bentuk produk dan jasa yang mereka hasilkan. Perusahaan harus mampu menentukan strategi pemasaran yang tepat agar dapat bertahan dan mencapai tujuan utama perusahaan. Salah satu upaya untuk bertahan dalam pasar yaitu dengan memberikan kepuasan kepada konsumen atas produk-produk yang diberikan.

Tjiptono (2016:96) faktor-faktor yang mempengaruhi loyalitas pelanggan terhadap suatu produk atau jasa dilihat dari kepuasan pelanggan dan kulitas pelayanan. Loyalitas konsumen menurut Kotler (2013:139) loyalitas konsumen adalah komitmen yang dipegang secara mendalam untuk membeli atau mendukung kembali produk atau jasa yang disukai di masa depan meski pengaruh situasi dan usaha pemasaran berpotensi.

Kotler (2013:53) terdapat lima faktor utama yang yang mempengaruhi yaitu, kualitas produk, kualitas pelayanan, emosional, harga dan biaya tambahan. Kotler (2013:35) kepuasan konsumen adalah perasaan senang atau kecewa seseorang yang berasal dari perbandingan antara kesannya terhadap kinerja (hasil) sesuatu produk dengan harapannya.
Selain kepuasan konsumen dan kualitas pelayanan, loyalitas konsumen juga dipengaruhi oleh harga. Harga merupakan faktor penentu dalam mengambil keputusan untuk membeli suatu produk barang dan jasa. Alma (2013:169) harga merupakan satuan moneter atau ukuran lainnya (termasuk barang dan jasa lainnya) yang ditukarkan agar memperoleh hak kepemilikan atau penggunaan suatu barang atau jasa. Peranan harga sangat penting untuk menjaga dan meningkatkan posisi dalam masyarakat. Tingginya harga biasanya diiringi dengan tingginya kualitas produk. Pilihan konsumen pada harga tinggi dengan harapan kualitas produk dan pelayanan yang diperoleh konsumen juga tinggi, sehingga konsumen puas meskipun harus membayar mahal.

Berdasarkan

sementara terhadap loyalitas konsumen, sebagian konsumen memilih untuk berkunjung dan berbelanja pada Indomaret Bagus Kuning Plaju, selain itu konsumen juga telah mencari informasi dari konsumen yang pernah berkunjung. Dari wawancara singkat dengan beberapa konsumen, kepuasan konsumen cukup terpenuhi dalam berbelanja di sana.

Berdasarkan hasil wawancara dan penelitian sebelumnya dengan jumlah sampel sebanyak 96 konsumen diperoleh hasil koefisen korelasi ( $r$ ) bernilai 0,491 hal ini menunjukkan bahwa hubungan antara harga dan loyalitas pelanggan Indomaret Bagus Kuning Plaju cukup kuat sebesar $24,11 \%$ dan sisanya $75,9 \%$ dipengaruhi oleh variabel lain yang tidak diteliti pada penelitian sebelumnya.

Berdasarkan temuan ini maka peneliti ingin melakukan penelitian lanjutan untuk mengkaji lebih lanjut 
melalui sebuah penelitian yang berjudul Pengaruh Kualitas Pelayanan dan Harga terhadap Kepuasan serta Dampaknya pada Loyalitas konsumen Indomaret Bagus Kuning Plaju.

\section{Rumusan Masalah:}

1. Apakah terdapat pengaruh kualitas pelayanan terhadap kepuasan konsumen Indomaret Bagus Kuning Plaju?

2. Apakah terdapat pengaruh harga terhadap kepuasan konsumen Indomaret Bagus Kuning Plaju?

3. Apakah terdapat pengaruh kualitas pelayanan terhadap loyalitas konsumen Indomaret Bagus Kuning Plaju?

4. Apakah terdapat pengaruh harga terhadap loyalitas konsumen Indomaret Bagus Kuning Plaju?

5. Apakah terdapat pengaruh kepuasan konsumen terhadap loyalitas konsumen Indomaret Bagus Kuning Plaju?

\section{Tujuan Penelitian}

1. Untuk mengatahui pengaruh kualitas pelayanan terhadap kepuasan konsumen Indomaret Bagus Kuning Plaju

2. Untuk mengetahui pengaruh harga terhadap kepuasan konsumen Indomaret Bagus Kuning Plaju

3. Untuk mengetahui pengaruh kualitas pelayanan terhadap loyalitas konsumen Indomaret Bagus Kuning Plaju

4. Untuk mengetahui pengaruh harga terhadap loyalitas konsumen Indomaret Bagus Kuning Plaju?

5. Untuk mengetahui pengaruh kepuasan konsumen terhadap loyalitas konsumen Indomaret Bagus Kuning Plaju

\section{TINJAUAN PUSTAKA}

\section{Kualitas Pelayanan}

Alma (2013:21), pelayanan adalah kegiatan-kegiatan yang tidak jelas, namun menyediakan kepuasan konsumen dan atau pemakai industri serta tidak terikat pada penjualan suatu produk atau pelayanan lainnya. Nanda (2016:89) kualitas pelayanan berkaitan erat dengan persepsi pelanggan tentang mutu suatu usaha. Sedangkan Tjiptono (2016:101) kualitas pelayanan adalah fungsi harapan konsumen pada pra pembelian pada proses penyediaan barang/jasa dan kualitas output yang diterima konsumen.

Pelayanan adalah suatu urutan kegiatan yang terjadi dalam interaksi langsung dengan orang-orang atau mesin secara fisik dan menyediakan kepuasan konsumen. Menurut Tjiptono (2016:58) pelayanan terbagi dua yaitu:

1) Pelayanan atas produk barang.

2) Pelayanan atas produk jasa.

Menurut Wolkins, dkk dalam Tjiptono (2016:66) enam prinsip pokok dalam kualitas pelayanan meliputi:

1) Kepemimpinan, strategi kualitas perusahaan harus merupakan inisiatif dan komitmen manajemen puncak.

2) Pendidikan, semua personil perusahaan dari harus memperoleh pendidikan mengenai kualitas.

3) Perencanaan, proses perencanaan strategik harus mencakup pengukuran dan tujuan kualitas yang dipergunakan dalam mengarahkan perusahaan untuk mencapai visinya.

4) Review, proses review merupakan satu-satunya alat yang paling efektif bagi manajemen untuk mengubah perilaku organisasional.

5) Komunikasi, implementasi strategi kualitas dalam organisasi 
dipengaruhi oleh proses komunikasi dalam perusahaan.

6) Penghargaan dan Pengakuan, penghargaan dan pengakuan merupakan aspek yang penting dalam implementasi strategi kualitas.

Menurut Kotler (2013:52) menyatakan ukuran pelayanan maksimal dapat dilihat pada indikatorindikator di bawah ini:

1) Wujud (Tangible), adalah peralatan, personel, dan bahan komunikasi.

2) Empati (Emphaty), yaitu yaitu kondisi memperhatikan dan memberikan perhatian pribadi kepada pelanggan Atau berarti perhatian yang diberikan pemberi jasa pada kliennya.

3) Kehandalan (Reliability), yaitu kemampuan melaksanakan jasa yang dijanjikan dengan andal dan akurat. Hal ini berarti jasa yang dikelola harus dilaksanakan dengan konsisten dan cermat.

4) Ketanggapan (Responsiveness), adalah kesediaan membantu pelanggan dan memberikan layanan tepat waktu. Hal ini berarti manajemen harus memberikan tanggapan dengan cepat dan Kreatif atas permintaan dan masalah konsumen.

5) Jaminan (Assurance), adalah pengetahuan dan kesopanan karyawan serta kemampuan mereka untuk menunjukan kepercayaan dan keyakinan.

Menurut Sudaryono (2016:152) menyatakan, agar layanan dapat memuaskan orang atau sekelompok orang yang dilayani, ada empat persyaratan pokok yaitu:

1) Tingkah laku yang sopan
2) Cara menyampaikan sesuatu yang berkaitan dengan apa yang seharusnya diterima oleh yang bersangkutan.

3) Waktu penyampaian yang tepat

4) Keramahtamahan

\section{Harga}

Harga merupakan faktor penting dalam mengambil keputusan untuk membeli suatu produk barang dan jasa. Alma (2013:169) harga merupakan satuan moneter atau ukuran lainnya (termasuk barang dan jasa lainnya) yang ditukarkan agar memperoleh hak kepemilikan atau penggunaan suatu barang atau jasa. Walton (2011:17) harga dan kualitas memiliki pengaruh yang tinggi terhadap kepuasan pelanggan, masih ada sedikit bukti empiris mengeksplorasi hubungan ini.

Dalam usahanya, perusahaan yang memasarkan barang atau jasa perlu penetapan harga yang tepat. Harga merupakan salah satu unsur pemasaran yang memberikan pemasukan atau pendekatan bagi perusahaan, harga juga merupakan komponen yang berpengaruh langsung terhadap laba perusahaan. Tjiptono (2016:151) harga merupakan satuan moneter atau ukuran lainnya (termasuk barang atau jasa lainnya) yang ditukarkan agar memperoleh hak atas penggunaan suatu barang.

Menurut Kotler (2013:43) harga merupakan sejumlah uang yang dibebankan atas suatu produk atau jasa, atau jumlah nilai yang ditukar konsumen untuk manfaat-manfaat yang diterima karena menggunakan produk atau jasa tersebut. Harga sering kali disebut sebagai indikator nilai, jika harga tersebut dihubungkan dengan manfaat yang diterima atas suatu barang atau jasa. Pada tingkat harga tertentu bila manfaat yang 
dirasakan konsumen meningkat, maka nilainya akan meningkat pula. Menurut Kotler (2013:452) bahwa strategi harga dapat berupa hal-hal berikut ini:

1) Penetapan Harga Jual, keputusan penetapan harga seperti halnya keputusan bauran pemasaran yang lainnya, harus berorientasi pada pembeli yang efektif, mencakup memahami seberapa besar nilai yang ditempatkan konsumen atas manfaat yang mereka terima dari produk dan penetapan harga yang sesuai dengan nilai pembeli.

2) Elastisitas Harga, responsif permintaan terhadap suatu perubahan harga jika permintaan hampir tidak berubah karena sedikit perubahan harga maka permintaan tersebut tidak elastis atau inelastis. Jika permintaan berubah banyak, maka perubahan tersebut elastis.

3) Perbandingan Harga Pesaing, faktor lain yang mempengaruhi keputusan penetapan harga perusahaan adalah harga pesaing dan kemungkinan reaksi pesaing atau tindakan penetapan harga yang dilakukan perusahaan. Seorang konsumen cenderung membeli suatu produk akan mengevaluasi serta nilai dari produk pembanding sejenis yang lainnya.

Harga mempunyai peranan penting secara makro dan secara mikro (Tjiptono, 2016:182) adalah:

1) Bagi perekonomian, harga produk mempunyai pengaruh tingkat upah, sewa, bunga dan laba. Harga merupakan regulator dasar dalam sistem perekonomian, karena harga berpengaruh terhadap alokasi faktor-faktor produksi. Seperti tenaga kerja, tanah, modal, waktu dan kewirausahaan.

2) Bagi konsumen, dalam penjualan ritel, ada segmen pembeli yang sangat sensistif terhadap faktor harga (menjadikan harga sebagai satu-satunya pertimbangan membeli produk) dan ada pula yang tidak.

3) Bagi perusahaan, jika dibandingkan dengan bauran pemasaran lainnya (produksi, distribusi, dan promosi) yang membutuhkan pengeluaran dana dalam jumlah besar, harga merupakan satu-satunya elemen bauran pemasaran yang mendatangkan pendapatan.

Menurut Kottler (2013:345) indikator empiris yang digunakan untuk menjelaskan variabel harga adalah sebagai berikut:

1) Ketergantungan harga

2) Kesesuaian harga dengan kualitas produk

3) Daya saing harga

4) Kesesuaian harga dengan manfaat produksi

5) Harga mempengaruhi daya beli konsumen

6) Harga dapat mempengaruhi konsumen dalam pengambilan keputusan.

Menurut Rangkuti (2016:159) mengemukakan indikator harga adalah sebagai berikut:

1) Respon terhadap Penetapan Harga, dengan melihat apakah konsumen telah menerima atau tidak harga yang ditetapkan produsen saat ini.

2) Kesesuaian Harga dengan Manfaat, harga yang ditetapkan produsen akan dianalisis konsumen dan disesuaikan dengan manfaat yang diperoleh dari mengunakan produk.

3) Harga mampu bersaing dengan produk pesaing, dalam mengkonsumsi suatu barang/jasa, konsumen selalu membanding harga produk yang sama dengan harga di tempat lain. 
Menurut Supranto (2012:50) Indikator harga adalah sebagai berikut:

1) Keterjangkauan harga, adalah harga sesuangguhnya dari suatu produk yang tertulis di suatu produk, yang harus dibayarkan oleh pelanggan , yang terdiri dari
(a) Harga yang ditawarkan mampu dijangkau secara finansial
(b) Penentuan harga harus sesuai dengan kuantitas produk sehingga pelanggan dapat mempertimbangkan dalam melakukan pembelian.

2) Potongan harga atau Diskon, adalah potongan yang diberikan penjual kepada pembeli sebagai dasar penghargaan atas aktivitas tertentu dari pembeli yang menyenangkan bagi penjual macam-macam diskon, yang terdiri dari:
(a) Diskon kuantitas
(b) Diskon musiman
(c) Diskon tunai
(d) Diskon Perdagangan

\section{Kepuasan Konsumen}

Kotler (2013:35), kepuasan konsumen adalah perasaan senang atau kecewa seseorang yang berasal dari perbandingan antara kesannya terhadap kinerja atau hasil suatu produk dan harapan-harapannya.

Alma (2013:238), kepuasan konsumen adalah tingkat perasaan konsumen setelah membandingkan dengan harapannya. Seorang pelanggan yang puas adalah pelanggan yang merasa mendapat value dari pemasok, produsen atau penyedia jasa.

Sunyoto (2013:37), menyatakan kepuasan konsumen adalah tingkat perasaan seseorang setelah membandingkan (kinerja atau hasil) yang dirasakan dibandingkan dengan harapannya. Konsumen dapat mengalami salah satu dari tiga tingkat kepuasan umum yaitu kalau kinerja di bawah harapan, konsumen akan merasa kecewa tetapi jika kinerja sesuai dengan harapan pelangganakan merasa puas dan apa bila kinerja bisa melebihi harapan maka pelanggan akan merasakan sangat puas senang atau gembira.

Supriyanto (2015:18), kepuasan konsumen merupakan label yang digunakan oleh konsumen untuk meringkas suatu himpunan aksi atau tindakan yang terlihat, terkait dengan produk atau jasa.

Menurut Kotler (2013:35) dalam menentukan tingkat kepuasan konsumen, terdapat lima faktor utama yaitu:

1) Kualitas produk, konsumen akan merasa puas bila hasil evaluasi mereka menunjukkan bahwa produk yang mereka gunakan berkualitas.

2) Kualitas pelayanan, terutama untuk industri jasa, konsumen akan merasa puas bila mereka mendapatkan pelayanan yang baik atau yang sesuai dengan yang diharapkan.

3) Emosional, konsumen akan merasa bangga dan mendapatkan keyakinan bahwa orang lain akan kagum terhadap dia bila menggunakan produk dengan merek tertentu yang cenderung mempunyai tingkat kepuasan yang lebih tinggi.

4) Harga, produk yang mempunyai kualitas yang sama tetapi menetapkan harga yang yang relatif murah akan memberikan nilai yang lebih tinggi kepada konsumennya.

5) Biaya, konsumen yang tidak perlu mengeluarkan biaya tambahan atau tidak perlu membuang waktu untuk mendapatkan suatu produk 
atau jasa cenderung puas terhadap produk atau jasa itu.

Tjiptono (2016:77) dalam mengevaluasi kepuasan terhadap produk, jasa, atau perusahaan tertentu, pelanggan umumnya mengacu pada berbagai faktor atau dimensi. Faktor yang sering digunakan dalam mengevaluasi kepuasan terhadap suatu produk antara lain meliputi:

1) Kinerja (performance) karakteristik operasi pokok dari produk inti (core product) yang dibeli, misalnya kecepatan, konsumen bahan bakar, jumlah penumpang yang dapat diangkut, kemudahan dan kenyamanan dalam mengemudi, dan sebagainya.

2) Ciri-ciri keistimewaan tambah (features) yaitu karakteristik sekunder atau pelengkap.

3) Keandalan (reliability) yaitu kemungkinan kecil akan mengalami kerusakan atau gagal dipakai.

4) Kesesuaian dengan spesifikasi (conformance to specifications) yaitu sejauhmana karakteristik desain dan operasi memenuhi standar - standar yang telah ditetapkan sebelumnya.

5) Daya tahan (durability) berkaitan dengan berapa lama produk tersebut dapat terus digunakan. Dimensi ini mencakup umur teknis maupun umur ekonomis penggunaan.

6) Service ability, meliputi kecepatan, kompetensi, kenyaman, mudah diperbaiki serta penanganan keluhan yang memuaskan. Pelayanan yang diberikan tidak hanya sebatas sebelum penjualan, tetapi juga selama proses penjualan hingga purna jual, yang mencakup pelayanan reparasi dan ketersediaan komponen yang dibutuhkan.

7) Estetika, yaitu daya tarik produk terhadap panca indera, misalnya bentuk fisik yang menarik

8) Model/desain, warna, dan sebagainya.

9) Kualitas yang dipersepsikan (perceived quality), yaitu citra dan reputasi produk serta tanggung jawab perusahaan terhadapnya.

Menurut Kotler (2013:77) bahwa indikator empiris yang digunakan untuk menjelaskan kepuasan konsumen adalah sebagai berikut:

1) Kepuasan Keseluruhan (Overall Satisfaction), adalah kepuasan secara keseluhan setelah mengkonsumsi produk yang ditawarkan produsen.

2) Harapan setelah Mengkonsumsi (Expectation Satisfaction), adalah harapan/keinginan yang diinginkan konsumen setelah mengkonsumsi produk.

3) Kepuasan Selama Mengkonsumsi (Experience Satisfaction), adalah tingkat kepuasan yang dialami konsumen selama konsumen masih menggunakan produk.

Selanjutnya Alma (2013:285) menyatakan terdapat 4 cara mengukur kepuasan konsumen yaitu sebagai berikut:

1) Sistem keluhan dan saran, perusahaan membuka kotak saran dan keluhan konsumen, informasi ini memungkinkan memberi ide dan masukan bagi perusahaan mengantisipasi dan tanggap terhadap kritik dan saran tersebut.

2) Survey Kepuasan Pelanggan, perusahaan melakukan survey untuk mendeteksi komentar konsumen.

3) Pembeli Bayangan, perusahaan menaruh orang tertentu sebagai 
pembeli pada perusahaan lain atau perusahaan sendiri.

4) Analisa Pelanggan yang Lari, konsumen yang hilang dihubungi dan diminta untuk mengungkapkan mengapa mereka pindah ke perusahaan lain.

Menurut Menurut Alma (2013:286) banyak sebab-sebab munculnya rasa tidak puas terhadap sesuatu antara lain:

1) Tidak sesuai harapan dengan kenyataan

2) Layanan selama proses menikmati jasa tidak memuaskan

3) Perilaku personil kurang memuaskan

4) Suasana dan kondisi fisik kurang menunjang

5) Biaya (Cost) terlalu tinggi, karena jarak terlalu jauh, banyak waktu terbuang dan harga tidak sesuai.

6) Promosi/iklan terlalu muluk, tidak sesuai dengan kenyataan.

\section{Loyalitas Konsumen}

Tujuan dari memasarkan suatu produk oleh semua perusahaan adalah untuk memiliki pelanggan yang loyal, loyalitas pelanggan dapat dibentuk melalui beberapa tahapan, mulai dari mencari calon pelanggan potensial sampai dengan advocate customers yang akan membawa keuntungan bagi perusahaan dan membuat rasa kepuasan dari seorang pelanggan.

Menurut Rangkuti (2013:60), Loyalitas konsumen adalah kesetiaan konsumen terhadap perusahaan, merek maupun produk. Sedangkan Griffin (2015:113) Loyalitas lebih mengacu pada wujud perilaku dari unit-unit pengambilan keputusan untuk melakukan pembelian secara terus menerus terhadap barang atau suatu jasa perusahaan yang dipilih.
Kotler (2013:139), loyalitas konsumen adalah komitmen yang dipegang secara mendalam untuk membeli atau mendukung kembali produk atau jasa yang disukai di masa depan meski pengaruh situasi dan usaha pemasaran berpotensi.

$$
\text { Selanjutnya Griffin }
$$
berpendapat bahwa seorang pelanggan dikatakan setia atau loyal apabila pelanggan tersebut menunjukkan perilaku pembelian secara teratur atau terdapat suatu kondisi dimana mewajibkan pelanggan membeli paling sedikit dua kali dalam selang waktu tertentu. Upaya memberikan kepuasan pelanggan dilakukan untuk mempengaruhi sikap pelanggan, sedangkan konsep loyalitas pelanggan lebih berkaitan dengan perilaku pelanggan daripada sikap dari pelanggan. Griffin (2015:77) menjelaskan bahwa ada 7 tahap dalam loyalitas seperti yang dijelaskan berikut:

1) Suspects, mencakup semua orang yang mungkin akan membeli jasa/barang perusahaan. Disebut sebagai suspects karena yakin bahwa mereka akan membeli tetapi belum tahu apapun mengenai perusahaan dan jasa/barang yang ditawarkan.

2) Prospects, adalah orang-orang yang memiliki kebutuhan akan produk atau jasa tertentu, dan mempunyai kemampuan untuk membelinya. Para prospect ini meskipun mereka belum melakukan pembelian, mereka telah mengetahui keberadaan perusahaan dan jasa/barang yang ditawarkan, karena seseorang telah merekomendasikan brang/jas tersebut padanya.

3) Disqualified Prospects, yaitu prospek yang telah diteliti mengetahui keberadaan jasa/barang tertentu, tetapi tidak 
mempunyai kebutuhan akan barang/jasa tersebut atau tidak mempunyai kemampuan untuk membeli barang/jasa tersebut.

4) First time customers, yaitu pandangan ketika akan membeli untuk yang pertama kalinya. Mereka masih dalam tahap sebagai pelanggan yang baru.

5) Repeat Costumer, yaitu pelanggan yang telah melakukan pembelian suatu produk sebanyak dua kali atau lebih. Mereka adalah yang melakukan pembelian atas produk yang sama sebanyak dua kali, atau membeli dua macam produk yang berbeda dalam dua kesempatan yang berbeda pula

6) Cilents, yaitu pelanggan membeli semua jasa/barang yang ditawarkan, yang mereka butuhkan. Mereka membeli secara teratur. Hubungan dengan jenis pelanggan ini sudah kuat dan berlangsung lama, yang membuat mereka tidak terpengaruh oleh tarikan persaingan jasa lainnya.

7) Advocates, Seperti halnya clients, advocates membeli seluruh jasa barang yang ditawarkan yang ia butuhkan, serta melakukan pembelian secara teratur. Sebagai tambahan, mereka juga mendorong teman-teman mereka yang lain agar membeli jasa/barang tersebut

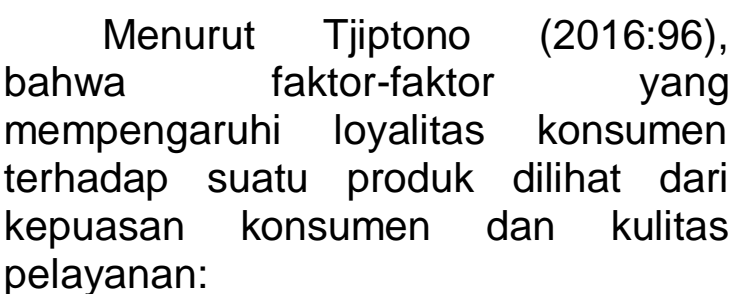

1) Kepuasan konsumen, merupakan pengukuran antara harapan pelanggan dengan kenyataan yang mereka terima atau rasakan.
2) Kualitas konsumen, adalah tingkat keunnggulan yang diharapkan dan pengendalian atas tingkat keunggulan tersebut dalam memenuhi keinginan konsumen.

Menurut Griffin (2015:77) terdapat empat jenis loyalitas yang muncul bila keterikatan rendah dan tinggi diklasifikasi silang dengan pola pembelian ulang, yang rendah dan tinggi. Adapun jenis - jenis loyalitas konsumen yaitu :

1) Tanpa Loyalitas, ada beberapa konsumen yang tidak mengembangkan loyalitas atau kesetiaan kepada suatu produk maupun jasa tertentu.

2) Loyalitas yang lemah (Inertia Loyality), merupakan sebuah jenis loyalitas konsumen yang dimana adanya keterikatan yang rendah dengan pembelian ulang yang tinggi. Konsumen yang memiliki sikap ini biasanya membeli berdasarkan kebiasaan.

3) Loyalitas Tersembunyi (Laten Loyality), jenis loyalitas tersembunyi merupakan sebuah kesetiaan atau keterikatan yang relatif tinggi yang disertai dengan tingkat pembelian ulang yang rendah.

4) Loyalitas Premium (Premium Loyalty), merupakan yang terjadi bilamana suatu tingkat keterikatan tinggi yang berjalan selaras dengan aktivitas pembelian kembali.

Menurut Zeithalm (2011:14), bahwa terdapat empat faktor yang mempengaruhi persepsi dan ekpektasi konsumen, yaitu sebagai berikut:

1) Didengar dari pelanggan lain (Word of mouth communication), konsumen memilih perusahaan yang diharapkan dapat 
memberikan pelayanan dengan kualitas tinggi berdasarkan rekomendasi relasi.

2) Kebutuhan Individu (Personal Needs), ekpektasi pelanggan sangat tergantung drai karakteristik individu/kebutuhan pribadi.

3) Pengalaman masa lalu (Post Experience), menggunakan pengalaman masa lalu sebagai alasan untuk meningkatkan ekspektasi konsumen

4) Komunikasi dengan pihak eksternal (External communication), perusahaan memberikan layanan dengan memberikan pesan-pesan secara langsung maupun tidak langsung kepada konsumen. Misalnya memberitahu ketika ada discount.

Menurut Kotler (2013:88) loyalitas konsumen merupakan komitmen seorang konsumen terhadap suatu pasar berdasarkan sikap positif dan tercermin dalam pembelian ulang secara konsisten. Indikator dari loyalitas konsumen tersebut adalah:

1) Kepercayaan (Trust), merupakan tanggapan kepercayaan konsumen terhadap pasar.

2) Psikologi Konsumen (Emotion Commitment), merupakan komitmen psikologi konsumen terhadap pasar

3) Perubahan Biaya (Switching cost), Merupakan tanggapan konsumen tentang beban yang diterima ketika terjadi perubahan.

4) Dari Mulut ke Mulut (Word of mouth), merupakan perilaku publisitas yang dilakukan konsumen terhadap pasar.

5) Bekerjasama (Cooperation), merupakan perilaku konsumen yang menunjukan sikap yang bekerja sama dengan pasar.
Terdapat empat macam dimensi loyalitas konsumen menurut Griffin (2015:31), yaitu:

1) Melakukan pembelian ulang secara teratur (Makes regular repeat purchase), komsumen melakukan pembelian secara continue pada suatu produk tertentu

2) Melakukan pembelian lini produk yang lainnya (Purchases across product and service lines), konsumen tidak hanya membeli jasa dan produk utama tetapi konsumen juga membeli lini produk dan jasa dari perusahaan yang sama

3) Memberikan referensi pada orang lain (Refers others), dimana konsumen melakukan komunikasi dari mulut ke mulut (Word of mouth) berkenaan dengan produk tersebut

4) Menunjukkan kekebalan terhadap tarikan dari pesaing (Demonstrates in immunity to the pull of the competition)

\section{METODE PENELITIAN}

\section{Desain Penelitian}

Metode penelitian dalam penelitian ini adalah penelitian asosiatif. (Sugiyono, 2017:6). Variabel bebas yaitu kualitas pelayanan jasa dan harga dengan kepuasan konsumen dan loyalitas konsumen sebagai variabel terikat.

\section{Data}

a. Jenis Data

Penelitian ini menggunakan data Cross Section, data cross section (Sugiyono, 2017:23).

\section{b. Sumber Data}

Sumber data adalah semua bahan dan materi yang dapat diolah lebih lanjut dalam sebuah penelitian, yang terdiri atas data primer dan data 
sekunder (Muhamad, 2008:103) yaitu sebagai berikut:

1) Data Primer

Adalah data yang didapat peneliti

dari sumber pertama baik individu/perorangan berupa jawaban responden dari pengisian kuesioner yang disebarkan.

2) Data Sekunder

Adalah sumber data yang diperoleh peneliti secara tidak langsung dengan melalui media perantara atau diperoleh dan dicatat oleh orang lain.

Data primer dalam penelitian ini adalah data yang diperoleh langsung dengan menyebar kuesioner terkait kualitas pelayanan jasa dan harga serta kepuasan konsumen. Data sekunder berupa data konsumen yang berkunjung di Indomaret Bagus Kuning Plaju.

\section{c. Skala Pengukuran}

Kategori skala pengukuran dalam penelitian ini menggunakan skala Likert. Pengukuran didasarkan beberapa karakteristik yang dimiliki oleh setiap peristiwa. (Sugiyono, 2017:132).

\section{Variabel}

Untuk menjelaskan indikatorindikator penelitian dari variabel bebas (independent) terdiri dari kualitas pelayanan jasa $\left(X_{1}\right)$ dan harga $\left(X_{2}\right)$ dengan variabel terikat kepuasan konsumen (Y) serta loyalitas konsumen $(Z)$.

\section{Populasi dan Sampel}

Populasi $(\mathrm{N})=\frac{2.472}{3}=824$
pelanggan

Sedangkan sampel adalah sebagian atau wakil populasi yang diteliti, untuk mengambil sampel dari populasi tersebut, digunakan Metode Accidental Sample yaitu sampel yang diambil dengan cara kebetulan pada saat konsumen sedang berbelanja atau berkunjung pada Indomaret Bagus Kuning Plaju. Sugiyono (2017:75) adapun rumus yang digunakan dengan pengambilan sampel adalah Rumus Slovin:

Sampel $(\mathrm{n})=\frac{824}{1+\left(824 \times 0,1^{2}\right)}=89,18$ $\approx 90$ pelanggan.

Dengan kreteria anggota sampel adalah konsumen yang pernah berbelanja di Indomaret Bagus Kuning Plaju tersebut lebih dari satu kali kunjungan.

\section{Teknik Pengumpulan Data}

Menurut Sugiyono (2017:402) teknik pengumpulan data dilihat dari segi cara, dilakukan dengan observasi, wawancara, kuesioner, dan dokumentasi, dapat diuraikan sebagai berikut:
1. Observasi
2. Wawancara.
3. Kuesioner
4. Dokumentasi (Field note)

\section{Pengujian Instrumen}

1. Uji Validitas Instrumen, (Sugiyono, 2017:177). Semakin tinggi akurasi suatu alat ukur, maka alat ukur tersebut semakin mengenai sasaran, atau semakin menunjukkan apa yang seharusnya diukur. Uji validitas dapat dilakukan dengan mengkorelasikan skor tiap butir dengan skor total yang merupakan jumlah tiap skor butir, dengan rumus Product Moment (Riduwan, 2012:109) dengan kaidah sebagai berikut:

a) Jika $r$ hitung $>r$ Tabel product moment, data tersebut valid. 
b) Jika $r$ hitung $\leq r$ Tabel product moment, berarti data tersebut tidak valid.

2. Uji Reliabilitas Instrumen, (Sugiyono, 2017:183). Pengujian reliabilitas instrumen dianalisis dengan metode alpha cronbach. Apabila Alpha Cronbach > standar 0,70 maka instrument dinyatakan reliable (Riduwan, 2012, :99).

\section{Metode Analisis}

a. Uji Normalitas Data, Alqifari (2016:123). Untuk mengetahui apakah data-data, variabel independent dan dependent mempunyai distribusi normal atau tidak. Menurut Riadi (2016:168) Data terdistribusi normal dalam model regresi dilihat dengan Komlmogorof Smirnof Test I, dengan $\alpha=0,05$ atau $5 \%$.

b. Uji Model

1) Uji Heteroskedastisitas, Alqifari (2016:137), bertujuan untuk mengetahui dalam model regresi terjadi ketidaksamaan varians dari residual pengamatan ke pengamatan yang lain.

2) Uji Multikolinieritas, pengujian ini bertujuan untuk menguji apakah model regresi ditemukan adanya korelasi antara variabel bebas (independent). Menurut Alqifari (2016:142), dasar acuannya jika nilai tolerance $>0,10$ dan nilai VIF < 10, maka, disimpulkan bahwa tidak ada multikolinearitas antar variabel independen dalam model regresi.

\section{Model Analisis}

Alat teknis analisis statistika yang digunakan adalah analisis jalur yang dihitung dengan dua persamaan struktural yaitu persamaan regresi yang menunjukkan hubungan yang dihipotesiskan, persamaan tersebut (Supranto 2016: 205) adalah:

$\mathrm{Y}=\mathrm{B}_{1} \mathrm{X}_{1}+\mathrm{B}_{2} \mathrm{X}_{2}+\mathrm{e}_{1}$
Keterangan:
$\mathrm{Y}=$ Kepuasan Konsumen
$\mathrm{B}_{1}=$ Koefisien jalur dari kualitas
pelayanan
$\mathrm{B}_{2}=$ Koefisien jalur dari harga
$\mathrm{X}_{1}=$ Kualitas Pelayanan
$\mathrm{X}_{2}=$ Harga
$\mathrm{e}_{2}=$ Nilai kekeliruan taksiran standar
(standar error)

$Z=B_{3} X_{1}+\beta_{4} X_{2}+\beta_{5} Y+e_{2}$ Keterangan:

$Z$ = Loyalitas Konsumen

$B_{3}=$ Koefisien jalur dari kualitas

pelayanan

$\mathrm{B}_{4}=$ Koefisien jalur dari harga

$B_{5}=$ Koefisien jalur dari kepuasan

konsumen

$\mathrm{X}_{1}=$ Kualitas Pelayanan Jasa

$\mathrm{X}_{2}=$ Harga

$\mathrm{Y}=$ Kepuasan Konsumen

$\mathrm{e}_{2}=$ Nilai kekeliruan taksiran standar (standar error)

\section{Uji Koefisien}

Hipotesis 1

$\mathrm{HO}$ : Tidak terdapat pengaruh signifikan kualitas pelayanan kepuasan terhadap Indomaret Plaju.

Ha: Terdapat pengaruh signifikan pelayanan kepuasan kualitas Indomaret Bagus Kuning Plaju.

\section{Hipotesis 2}

HO: Tidak terdapat pengaruh signifikan harga terhadap kepuasan konsumen 
Indomaret Bagus Kuning Plaju.

Ha: $\quad$ Terdapat pengaruh signifikan harga terhadap kepuasan konsumen Indomaret Bagus Kuning Plaju.

\section{Hipotesis 3}

H0: Tidak terdapat pengaruh signifikan kualitas pelayanan terhadap loyalitas konsumen Indomaret Bagus Kuning Plaju.

Ha: Terdapat pengaruh signifikan kualitas pelayanan terhadap loyalitas konsumen Indomaret Bagus Kuning Plaju.

\section{Hipotesis 4}

H0: Tidak terdapat pengaruh signifikan harga terhadap loyalitas Indomaret Bagus Kuning Plaju.

Ha: Terdapat pengaruh signifikan harga terhadap loyalitas konsumen Indomaret Bagus Kuning Plaju.

\section{Hipotesis 5}

H0: Tidak terdapat pengaruh signifikan kepuasan konsumen terhadap loyalitas konsumen Indomaret Bagus Kuning Plaju.

Ha: Terdapat pengaruh signifikan kepuasan konsumen terhadap loyalitas konsumen Indomaret Bagus Kuning Plaju.

HASIL DAN PEMBAHASAN

1. Hasil Pengujian Instrumen a. Hasil Pengujian Validitas

Tabel 1 Hasil Uji Validitas Variabel Kualitas Pelayanan Jasa $\left(X_{1}\right)$

\begin{tabular}{|c|c|c|c|}
\hline $\begin{array}{c}\text { Item } \\
\text { Indikator }\end{array}$ & $\begin{array}{c}\text { Corrected } \\
\text { Item-Total } \\
\text { Correlation }\end{array}$ & $\begin{array}{c}\mathrm{r} \text { Tabel } \\
\mathrm{n}=90\end{array}$ & Kesimpulan \\
\hline $\mathrm{X} 1.1$ & 0,488 & 0,361 & Valid \\
$\mathrm{X} 1.2$ & 0,391 & 0,361 & Valid \\
$\mathrm{X} 1.3$ & 0,449 & 0,361 & Valid \\
$\mathrm{X} 1.4$ & 0,403 & 0,361 & Valid \\
$\mathrm{X} 1.5$ & 0,581 & 0,361 & Valid \\
$\mathrm{X} 1.6$ & 0,543 & 0,361 & Valid \\
$\mathrm{X} 1.7$ & 0,475 & 0,361 & Valid \\
$\mathrm{X} 1.8$ & 0,442 & 0,361 & Valid \\
$\mathrm{X} 1.9$ & 0,420 & 0,361 & Valid \\
$\mathrm{X} 1.10$ & 0,462 & 0,361 & Valid \\
\hline
\end{tabular}


Tabel 2 Hasil Uji Validitas Variabel Harga $\left(\mathrm{X}_{2}\right)$

\begin{tabular}{|c|c|c|c|}
\hline $\begin{array}{c}\text { Item } \\
\text { Indikator }\end{array}$ & $\begin{array}{c}\text { Corrected } \\
\text { Item-Total } \\
\text { Correlation }\end{array}$ & $\begin{array}{c}\mathrm{r} \text { Tabel } \\
\mathrm{n}=90\end{array}$ & Kesimpulan \\
\hline X2.1 & 0,530 & 0,361 & Valid \\
X2.2 & 0,408 & 0,361 & Valid \\
X2.3 & 0,488 & 0,361 & Valid \\
X2.4 & 0,548 & 0,361 & Valid \\
X2.5 & 0,477 & 0,361 & Valid \\
X2.6 & 0,606 & 0,361 & Valid \\
X2.7 & 0,747 & 0,361 & Valid \\
\hline
\end{tabular}

Tabel 3 Hasil Uji Validitas Variabel Kepuasan Konsumen (Y)

\begin{tabular}{|c|c|c|c|}
\hline $\begin{array}{c}\text { Item } \\
\text { Indikator }\end{array}$ & $\begin{array}{c}\text { Corrected } \\
\text { Item-Total } \\
\text { Correlation }\end{array}$ & $\begin{array}{c}\mathrm{r} \text { Tabel } \\
\mathrm{n}=90\end{array}$ & Kesimpulan \\
\hline Y.1 & 0,383 & 0,361 & Valid \\
Y.2 & 0,442 & 0,361 & Valid \\
Y.3 & 0,452 & 0,361 & Valid \\
Y.4 & 0,487 & 0,361 & Valid \\
Y.5 & 0,462 & 0,361 & Valid \\
Y.6 & 0,545 & 0,361 & Valid \\
Y.7 & 0,414 & 0,361 & Valid \\
Y.8 & 0,411 & 0,361 & Valid \\
\hline
\end{tabular}

Tabel 4 Hasil Uji Validitas Variabel Loyalitas Konsumen (Z)

\begin{tabular}{|c|c|c|c|}
\hline $\begin{array}{c}\text { Item } \\
\text { Indikator }\end{array}$ & $\begin{array}{c}\text { Corrected } \\
\text { Item-Total } \\
\text { Correlation }\end{array}$ & $\begin{array}{c}\mathrm{r} \text { Tabel } \\
\mathrm{n}=90\end{array}$ & Kesimpulan \\
\hline Z.1 & 0,536 & 0,361 & Valid \\
Z.2 & 0,548 & 0,361 & Valid \\
Z.3 & 0,522 & 0,361 & Valid \\
Z.4 & 0,504 & 0,361 & Valid \\
Z.5 & 0,366 & 0,361 & Valid \\
Z.6 & 0,552 & 0,361 & Valid \\
Z.7 & 0,385 & 0,361 & Valid \\
Z.8 & 0,413 & 0,361 & Valid \\
\hline
\end{tabular}


b. Hasil Pengujian Reliabilitas

Tabel 5 Hasil Uji Reliabilitas

\begin{tabular}{|c|l|c|c|c|}
\hline No & \multicolumn{1}{|c|}{ Variabel } & $\begin{array}{c}\text { Cronbach's } \\
\text { Alpha }\end{array}$ & $\begin{array}{c}\text { Nilai } \\
\text { Alpha }\end{array}$ & $\begin{array}{c}\text { Hasil Uji } \\
\text { Reliabilitas }\end{array}$ \\
\hline 1 & Kualitas Pelayanan Jasa $\left(\mathrm{X}_{1}\right)$ & 0,793 & 0,70 & Reliabel \\
\hline 2 & Harga $\left(\mathrm{X}_{2}\right)$ & 0,807 & 0,70 & Reliabel \\
\hline 3 & Kepuasan Konsumen $(\mathrm{Y})$ & 0,747 & 0,70 & Reliabel \\
\hline 4 & Loyalitas Konsumen $(\mathrm{Y})$ & 0,775 & 0,70 & Reliabel \\
\hline
\end{tabular}

2. Deskriptif Statistik Data

Tabel 6 Hasil Deskriptif Statistik Data

\begin{tabular}{|l|r|r|r|r|}
\hline & Pelayanan.jasa & Harga & $\begin{array}{c}\text { Kepuasan. } \\
\text { Kons }\end{array}$ & Loyalitas.Kons \\
\hline N Valid & 90 & 90 & 90 & 90 \\
$\quad$ Missing & 0 & 0 & 0 & 0 \\
Mean & 2,84663 & 2,79573 & 2,40663 & 3,01910 \\
Std. Error of & 0,055586 & 0,055150 & 0,053051 & 0,052666 \\
Mean & & & & \\
Median & 2,83000 & 2,77000 & 2,38000 & 2,99000 \\
Mode & 2,100 & 2,950 & $2,060^{a}$ & $2,630^{a}$ \\
Std. Deviation & 0,524393 & 0,520288 & 0,500479 & 0,496848 \\
Variance & 0,275 & 0,271 & 0,250 & 0,247 \\
Skewness & 0,233 & 0,150 & 0,147 & 0,005 \\
Std. Error of & 0,255 & 0,255 & 0,255 & 0,255 \\
Skewness & & & & \\
Kurtosis & $-0,873$ & $-0,214$ & $-0,376$ & $-0,421$ \\
Std. Error of & 0,506 & 0,506 & 0,506 & 0,506 \\
Kurtosis & & & & \\
Range & 2,230 & 2,400 & 2,210 & 2,220 \\
Minimum & 1,840 & 1,660 & 1,350 & 1,970 \\
Maximum & 4,070 & 4,060 & 3,560 & 4,190 \\
Sum & 253,350 & 248,820 & 214,190 & 268,700 \\
\hline
\end{tabular}

Karakteristik Responden

Tabel 7 Distribusi Responden

Berdasarkan Jenis Kelamin

\begin{tabular}{|c|c|c|c|}
\hline No & $\begin{array}{c}\text { Jenis } \\
\text { Kelamin }\end{array}$ & $\begin{array}{c}\text { Jumlah } \\
\text { (Orang) }\end{array}$ & Persentase(\%) \\
\hline 1 & Laki-laki & 40 & 44,44 \\
\hline 2 & Perempuan & 50 & 55,56 \\
\hline \multicolumn{2}{|c|}{ Total } & 96 & 100 \\
\hline
\end{tabular}


Tabel 8 Distribusi Responden Berdasarkan Umur

\begin{tabular}{|c|c|c|c|}
\hline No & $\begin{array}{c}\text { Rentang Usia } \\
\text { Responden } \\
\text { (Tahun) }\end{array}$ & $\begin{array}{l}\text { Jumlah } \\
\text { (Orang) }\end{array}$ & $\begin{array}{c}\text { Persentase } \\
(\%)\end{array}$ \\
\hline 1 & $15-20$ & 25 & 26,04 \\
\hline 2 & $21-25$ & 30 & 31,25 \\
\hline 3 & $26-30$ & 10 & 10,42 \\
\hline 4 & $31-35$ & 10 & 12,50 \\
\hline 5 & $36-40$ & 6 & 8,33 \\
\hline 6 & Lebih dari 40 tahun & 9 & 11,46 \\
\hline & Total & 90 & 100 \\
\hline
\end{tabular}

Tabel 9 Distribusi Responden Berdasarkan Pekerjaan

\begin{tabular}{|c|c|c|c|}
\hline No & Pekerjaan & $\begin{array}{c}\text { Jumlah } \\
\text { (Orang) }\end{array}$ & $\begin{array}{c}\text { Persentase } \\
(\%)\end{array}$ \\
\hline 1 & Pegawai Negeri & 15 & 15,63 \\
\hline 2 & Pegawai Swasta & 15 & 15,63 \\
\hline 3 & Pedagang & 15 & 15,63 \\
\hline 4 & Buruh & 10 & 16,67 \\
\hline 5 & Pelajar / Mahasiswa & 35 & 36,44 \\
\hline \multicolumn{2}{r|}{ Total } & 90 & 100 \\
\hline
\end{tabular}

\section{Deskripsi Jawaban Responden}

Tabel 10 Distribusi frekuensi Variabel Kualitas Pelayanan Jasa $\left(\mathrm{X}_{1}\right)$

\begin{tabular}{|c|c|c|c|c|c|c|}
\hline \multirow[t]{2}{*}{ No } & \multirow[t]{2}{*}{ Pernyataan } & STS & TS & $\mathrm{N}$ & S & SS \\
\hline & & $(1)$ & $(2)$ & (3) & (4) & (5) \\
\hline & Tangible & \multirow[b]{2}{*}{$\begin{array}{c}0 \\
(0 \%) \\
\end{array}$} & \multirow[b]{2}{*}{$\begin{array}{c}3 \\
(3,4 \%)\end{array}$} & \multirow[b]{2}{*}{$\begin{array}{c}21 \\
(23,6 \%)\end{array}$} & \multirow[b]{2}{*}{$\begin{array}{c}47 \\
(52,8 \%)\end{array}$} & \multirow[b]{2}{*}{$\begin{array}{c}18 \\
(20,2 \%)\end{array}$} \\
\hline 1 & $\begin{array}{l}\text { Indomaret Bagus Kuning Plaju } \\
\text { memiliki fasilitas lengkap. }\end{array}$ & & & & & \\
\hline 2 & $\begin{array}{l}\text { Indomaret Bagus Kuning Plaju } \\
\text { menunjukkan kebersihan fasilitas fisik }\end{array}$ & $\begin{array}{c}0 \\
(0 \%)\end{array}$ & $\begin{array}{c}5 \\
(5,6 \%)\end{array}$ & $\begin{array}{c}22 \\
(24,7 \%)\end{array}$ & $\begin{array}{c}46 \\
(51,7 \%)\end{array}$ & $\begin{array}{c}16 \\
(18 \%)\end{array}$ \\
\hline \multirow[t]{2}{*}{3} & Emphaty & \multirow[b]{2}{*}{$\begin{array}{c}0 \\
(0 \%)\end{array}$} & \multirow[b]{2}{*}{$\begin{array}{c}2 \\
(2,2 \%)\end{array}$} & \multirow[b]{2}{*}{$\begin{array}{c}21 \\
(23,6 \%)\end{array}$} & \multirow[b]{2}{*}{$\begin{array}{c}44 \\
(49,4 \%)\end{array}$} & \multirow[b]{2}{*}{$\begin{array}{c}22 \\
(24,7 \%)\end{array}$} \\
\hline & $\begin{array}{l}\text { Karyawan memperhatikan kebutuhan } \\
\text { konsumen dengan sungguh-sungguh. }\end{array}$ & & & & & \\
\hline 4 & $\begin{array}{l}\text { Akses Indomaret Bagus Kuning Plaju } \\
\text { mudah dijangkau oleh konsumen. }\end{array}$ & $\begin{array}{c}0 \\
(0 \%)\end{array}$ & $\begin{array}{c}3 \\
(3,4 \%)\end{array}$ & $\begin{array}{c}17 \\
(19,1 \%)\end{array}$ & $\begin{array}{c}47 \\
(52,8 \%)\end{array}$ & $\begin{array}{c}22 \\
(24,7 \%)\end{array}$ \\
\hline \multirow[t]{2}{*}{5} & Reliability & \multirow[b]{2}{*}{$\begin{array}{c}0 \\
(0 \%)\end{array}$} & \multirow[b]{2}{*}{$\begin{array}{c}1 \\
(1,1 \%)\end{array}$} & \multirow[b]{2}{*}{$\begin{array}{c}22 \\
(24,7 \%)\end{array}$} & \multirow[b]{2}{*}{$\begin{array}{c}52 \\
(58,4 \%)\end{array}$} & \multirow[b]{2}{*}{$\begin{array}{c}14 \\
(15,7 \%)\end{array}$} \\
\hline & $\begin{array}{l}\text { Indomaret Bagus Kuning Plaju } \\
\text { menyediakan jasa pelayanan yang } \\
\text { baik dari awal pemesanan hingga } \\
\text { akhir acara berlangsung. }\end{array}$ & & & & & \\
\hline 6 & $\begin{array}{l}\text { Indomaret Bagus Kuning Plaju } \\
\text { memberikan pelayanan maksimal } \\
\text { sesuai dengan yang dijanjikan. }\end{array}$ & $\begin{array}{c}0 \\
(0 \%)\end{array}$ & $\begin{array}{c}0 \\
(0 \%)\end{array}$ & $\begin{array}{c}23 \\
(25,8 \%)\end{array}$ & $\begin{array}{c}50 \\
(56,2 \%)\end{array}$ & $\begin{array}{c}16 \\
(18 \%)\end{array}$ \\
\hline \multirow[t]{2}{*}{7} & Responsiveness & \multirow[b]{2}{*}{$\begin{array}{c}0 \\
(0 \%)\end{array}$} & \multirow[b]{2}{*}{$\begin{array}{c}24 \\
(27 \%)\end{array}$} & \multirow[b]{2}{*}{$\begin{array}{c}35 \\
(39,3 \%)\end{array}$} & \multirow[b]{2}{*}{$\begin{array}{c}26 \\
(29,2 \%)\end{array}$} & \multirow[b]{2}{*}{$\begin{array}{c}2 \\
(4,5 \%)\end{array}$} \\
\hline & $\begin{array}{l}\text { Karyawan bersedia memberikan } \\
\text { pelayanan dan membantu kesulitan } \\
\text { konsumen dengan cepat. }\end{array}$ & & & & & \\
\hline
\end{tabular}




\begin{tabular}{|c|l|c|c|c|c|c|}
\hline 8 & $\begin{array}{l}\text { Karyawan bersedia meluangkan } \\
\text { waktu khusus untuk menanggapi } \\
\text { permintaan konsumen dengan cepat. }\end{array}$ & $\begin{array}{c}0 \\
(0 \%)\end{array}$ & $\begin{array}{c}21 \\
(23,6 \% \\
5\end{array}$ & $\begin{array}{c}41 \\
(46,1 \%)\end{array}$ & $\begin{array}{c}23 \\
(25,8 \%)\end{array}$ & $\begin{array}{c}4 \\
(4,5 \%)\end{array}$ \\
\hline \multirow{2}{*}{9} & Assurance & $\begin{array}{l}\text { Reputasi Indomaret Bagus Kuning } \\
\text { Plaju mampu memberikan jaminan } \\
\text { pelayanan maksimal. }\end{array}$ & $\begin{array}{c}13 \\
(0 \%)\end{array}$ & $\begin{array}{c}(14,6 \% \\
(53,9 \%)\end{array}$ & $\begin{array}{c}26 \\
(29,2 \%)\end{array}$ & $\begin{array}{c}2 \\
(2,2 \%)\end{array}$ \\
\hline 10 & $\begin{array}{l}\text { Karyawan Indomaret Bagus Kuning } \\
\text { Plaju memiliki kompetensi dalam } \\
\text { pelayanan maksimal. }\end{array}$ & $\begin{array}{c}0 \\
(0 \%)\end{array}$ & $\begin{array}{c}11 \\
(12,4 \% \\
(5)\end{array}$ & 48 & 28 & 2 \\
$(53,9 \%)$ & $(31,5 \%)$ & $(2,2 \%)$ \\
\hline
\end{tabular}

Tabel 11 Distribusi frekuensi Variabel Harga $\left(\mathrm{X}_{2}\right)$

\begin{tabular}{|c|c|c|c|c|c|c|}
\hline \multirow[t]{2}{*}{ No } & \multirow[t]{2}{*}{ Pernyataan } & STS & TS & $\mathrm{N}$ & $S$ & SS \\
\hline & & (1) & (2) & (3) & (4) & (5) \\
\hline 1 & $\begin{array}{l}\text { Keterjangkauan Harga } \\
\text { Harga yang ditawarkan } \\
\text { Indomaret Bagus Kuning Plaju } \\
\text { terjangkau oleh seluruh } \\
\text { kalangan konsumen. }\end{array}$ & $\begin{array}{c}0 \\
(0 \%)\end{array}$ & $\begin{array}{c}0 \\
(0 \%)\end{array}$ & $\begin{array}{c}21 \\
(23,6 \%)\end{array}$ & $\begin{array}{c}36 \\
(40,4 \%)\end{array}$ & $\begin{array}{c}32 \\
(36 \%)\end{array}$ \\
\hline 2 & $\begin{array}{l}\text { Terjangkau secara finansial } \\
\text { Konsumen membeli di } \\
\text { Indomaret Bagus Kuning Plaju } \\
\text { dan mampu membayar harga } \\
\text { yang ditetapkan. }\end{array}$ & $\begin{array}{c}0 \\
(0 \%)\end{array}$ & $\begin{array}{c}2 \\
(2,2 \%)\end{array}$ & $\begin{array}{c}18 \\
(20,2 \%)\end{array}$ & $\begin{array}{c}43 \\
(48,3 \%)\end{array}$ & $\begin{array}{c}26 \\
(29,2 \%)\end{array}$ \\
\hline 3 & $\begin{array}{l}\text { Pembelian karena kualitas } \\
\text { Harga yang ditawarkan } \\
\text { Indomaret Bagus Kuning Plaju } \\
\text { sesuai dengan kuantitas produk } \\
\text { yang ditawarkan. }\end{array}$ & $\begin{array}{c}0 \\
(0 \%)\end{array}$ & $\begin{array}{c}5 \\
(5,6 \%)\end{array}$ & $\begin{array}{c}20 \\
(22,5 \%)\end{array}$ & $\begin{array}{c}43 \\
(48,3 \%)\end{array}$ & $\begin{array}{c}21 \\
(23,6 \%)\end{array}$ \\
\hline 4 & $\begin{array}{l}\text { Potongan harga } \\
\text { Indomaret Bagus Kuning Plaju } \\
\text { sering memberikan potongan } \\
\text { harga kepada konsumen. }\end{array}$ & $\begin{array}{c}0 \\
(0 \%)\end{array}$ & $\begin{array}{c}11 \\
(12,4 \%)\end{array}$ & $\begin{array}{c}51 \\
(57,3 \%)\end{array}$ & $\begin{array}{c}21 \\
(23,6 \%)\end{array}$ & $\begin{array}{c}6 \\
(6,7 \%)\end{array}$ \\
\hline 5 & $\begin{array}{l}\text { Diskon Kuantitas } \\
\text { Pihak Indomaret Bagus Kuning } \\
\text { Plaju memberikan potongan } \\
\text { harga bagi konsumen yang } \\
\text { memiliki kartu member. }\end{array}$ & $\begin{array}{c}0 \\
(0 \%)\end{array}$ & $\begin{array}{c}8 \\
(9 \%)\end{array}$ & $\begin{array}{c}51 \\
(57,3 \%)\end{array}$ & $\begin{array}{c}29 \\
(32,6 \%)\end{array}$ & $\begin{array}{c}1 \\
(1,1 \%)\end{array}$ \\
\hline 6 & $\begin{array}{l}\text { Diskon Musiman } \\
\text { Indomaret Bagus Kuning Plaju } \\
\text { memberikan potongan harga } \\
\text { pada konsumen pada saat } \\
\text { bulan suci ramadhan. }\end{array}$ & $\begin{array}{c}0 \\
(0 \%)\end{array}$ & $\begin{array}{c}8 \\
(9 \%)\end{array}$ & $\begin{array}{c}52 \\
(58,4 \%)\end{array}$ & $\begin{array}{c}19 \\
(21,3 \%)\end{array}$ & $\begin{array}{c}10 \\
(11,2 \%)\end{array}$ \\
\hline 7 & $\begin{array}{l}\text { Diskon Tunai } \\
\text { Indomaret Bagus Kuning Plaju } \\
\text { memberikan diskon dalam } \\
\text { bentuk uang tunai ketika } \\
\text { konsumen membayar dimuka. }\end{array}$ & $\begin{array}{c}0 \\
(0 \%)\end{array}$ & $\begin{array}{c}12 \\
(13,5 \%)\end{array}$ & $\begin{array}{c}50 \\
(56,2 \%)\end{array}$ & $\begin{array}{c}14 \\
(15,7 \%)\end{array}$ & $\begin{array}{c}13 \\
(14,6 \%)\end{array}$ \\
\hline
\end{tabular}


Tabel 12 Distribusi Frekuensi Variabel Kepuasan Konsumen (Y)

\begin{tabular}{|c|c|c|c|c|c|c|}
\hline \multirow[t]{2}{*}{ No } & \multirow[t]{2}{*}{ Pernyataan } & STS & TS & $\mathrm{N}$ & $\mathrm{S}$ & SS \\
\hline & & (1) & (2) & (3) & (4) & (5) \\
\hline 1 & $\begin{array}{l}\text { Kinerja } \\
\text { Konsumen merasa puas atas } \\
\text { performance yang ditunjukkan } \\
\text { Indomaret Bagus Kuning Plaju } \\
\text { dalam memenuhi kebutuhan. }\end{array}$ & $\begin{array}{c}0 \\
(0 \%)\end{array}$ & $\begin{array}{c}0 \\
(0 \%)\end{array}$ & $\begin{array}{c}25 \\
(28,1 \%)\end{array}$ & $\begin{array}{c}57 \\
(64 \%)\end{array}$ & $\begin{array}{c}7 \\
(7,9 \%)\end{array}$ \\
\hline 2 & $\begin{array}{l}\text { Keistimewaan } \\
\text { Masing-masing Indomaret } \\
\text { Bagus Kuning Plaju memiliki } \\
\text { keistimewaan tersendiri yang } \\
\text { membedakan dengan yang } \\
\text { lain }\end{array}$ & $\begin{array}{c}0 \\
(0 \%)\end{array}$ & $\begin{array}{c}0 \\
(0 \%)\end{array}$ & $\begin{array}{c}25 \\
(28,1 \%)\end{array}$ & $\begin{array}{c}48 \\
(53,9 \%)\end{array}$ & $\begin{array}{c}16 \\
(18 \%)\end{array}$ \\
\hline 3 & $\begin{array}{l}\text { Keandalan } \\
\text { Konsumen puas dengan } \\
\text { jaminan kecilnya kemungkinan } \\
\text { gagalnya acara event yang } \\
\text { diadakan. }\end{array}$ & $\begin{array}{c}0 \\
(0 \%)\end{array}$ & $\begin{array}{c}8 \\
(9 \%)\end{array}$ & $\begin{array}{c}51 \\
(57,3 \%)\end{array}$ & $\begin{array}{c}29 \\
(32,6 \%)\end{array}$ & $\begin{array}{c}1 \\
(1,1 \%)\end{array}$ \\
\hline 4 & $\begin{array}{l}\text { Kesesuaian dengan } \\
\text { Spesifikasi } \\
\text { Konsumen puas dengan } \\
\text { kesesuaian produk yang } \\
\text { ditawarkan dengan yang } \\
\text { digunakan. }\end{array}$ & $\begin{array}{c}0 \\
(0 \%)\end{array}$ & $\begin{array}{c}0 \\
(0 \%)\end{array}$ & $\begin{array}{c}21 \\
(23,6 \%)\end{array}$ & $\begin{array}{c}55 \\
(61,8 \%)\end{array}$ & $\begin{array}{c}13 \\
(14,6 \%)\end{array}$ \\
\hline 5 & $\begin{array}{l}\text { Daya Tahan } \\
\text { Konsumen puas dengan } \\
\text { ketahanan produk yang } \\
\text { tersedia. }\end{array}$ & $\begin{array}{c}0 \\
(0 \%)\end{array}$ & $\begin{array}{c}10 \\
(11,2 \%)\end{array}$ & $\begin{array}{c}55 \\
(61,8 \%)\end{array}$ & $\begin{array}{c}21 \\
(32,6 \%)\end{array}$ & $\begin{array}{c}3 \\
(3,4 \%)\end{array}$ \\
\hline 6 & $\begin{array}{l}\text { Servicetability } \\
\text { Konsumen puas dengan } \\
\text { kecepatan dan kompetensi } \\
\text { layanan. }\end{array}$ & $\begin{array}{c}0 \\
(0 \%)\end{array}$ & $\begin{array}{c}13 \\
(14,6 \%)\end{array}$ & $\begin{array}{c}48 \\
(53,9 \%)\end{array}$ & $\begin{array}{c}21 \\
(23,6 \%)\end{array}$ & $\begin{array}{c}7 \\
(7,9 \%)\end{array}$ \\
\hline 7 & $\begin{array}{l}\text { Estetika } \\
\text { Desain, warna dan model } \\
\text { penataan ruang dan etalase } \\
\text { memberikan rasa puas bagi } \\
\text { konsumen }\end{array}$ & $\begin{array}{c}0 \\
(0 \%)\end{array}$ & $\begin{array}{c}24 \\
(27 \%)\end{array}$ & $\begin{array}{c}35 \\
(39,3 \%)\end{array}$ & $\begin{array}{c}26 \\
(29,2 \%)\end{array}$ & $\begin{array}{c}4 \\
(4,5 \%)\end{array}$ \\
\hline 8 & $\begin{array}{l}\text { Kualitas yang dipersepsikan } \\
\text { Konsumen puas karena dapat } \\
\text { berbelanja. }\end{array}$ & $\begin{array}{c}0 \\
(0 \%)\end{array}$ & $\begin{array}{c}0 \\
(0 \%)\end{array}$ & $\begin{array}{c}23 \\
(25,8 \%)\end{array}$ & $\begin{array}{c}50 \\
(56,2 \%)\end{array}$ & $\begin{array}{c}16 \\
(18 \%) \\
\end{array}$ \\
\hline
\end{tabular}


Tabel 13 Distribusi frekuensi Variabel Loyalitas Konsumen (Z)

\begin{tabular}{|c|c|c|c|c|c|c|}
\hline \multirow[b]{2}{*}{ No } & \multirow[b]{2}{*}{ Pernyataan } & STS & TS & $\mathrm{N}$ & $\mathrm{S}$ & SS \\
\hline & & (1) & (2) & (3) & (4) & (5) \\
\hline & Pembelian Ulang & \multirow[b]{2}{*}{$\begin{array}{c}0 \\
(0 \%)\end{array}$} & \multirow[b]{2}{*}{$\begin{array}{c}18 \\
(20,2 \%)\end{array}$} & \multirow[b]{2}{*}{$\begin{array}{c}46 \\
(51,7 \%)\end{array}$} & \multirow[b]{2}{*}{$\begin{array}{c}22 \\
(24,7 \%)\end{array}$} & \multirow[b]{2}{*}{$\begin{array}{c}3 \\
(3,4 \%)\end{array}$} \\
\hline 1 & $\begin{array}{l}\text { Konsumen kembali menggunakan } \\
\text { jasa Indomaret Bagus Kuning } \\
\text { Plaju untuk membeli sesuatu. }\end{array}$ & & & & & \\
\hline \multirow[t]{2}{*}{2} & $\begin{array}{l}\text { Konsumen menggunakan jasa } \\
\text { Indomaret Bagus Kuning Plaju } \\
\text { secara teratur. }\end{array}$ & $\begin{array}{c}0 \\
(0 \%)\end{array}$ & $\begin{array}{c}15 \\
(16,9 \%)\end{array}$ & $\begin{array}{c}47 \\
(52,8 \%)\end{array}$ & $\begin{array}{c}21 \\
(23,6 \%)\end{array}$ & $\begin{array}{c}6 \\
(6,7 \%)\end{array}$ \\
\hline & \multicolumn{6}{|l|}{ Pembelian antar Produk } \\
\hline 3 & $\begin{array}{l}\text { Konsumen menggunakan jasa } \\
\text { Indomaret Bagus Kuning Plaju } \\
\text { untuk keperluan lain }\end{array}$ & $\begin{array}{c}0 \\
(0 \%)\end{array}$ & $\begin{array}{c}1 \\
(1,1 \%)\end{array}$ & $\begin{array}{c}16 \\
(18 \%)\end{array}$ & $\begin{array}{c}53 \\
(59,6 \%)\end{array}$ & $\begin{array}{c}19 \\
(21,3 \%)\end{array}$ \\
\hline \multirow[t]{2}{*}{4} & $\begin{array}{l}\text { Konsumen tidak hanya } \\
\text { menggunakan produk/jasa utama. }\end{array}$ & $\begin{array}{c}0 \\
(0 \%)\end{array}$ & $\begin{array}{c}1 \\
(1,1 \%)\end{array}$ & $\begin{array}{c}10 \\
(22,5 \%)\end{array}$ & $\begin{array}{c}61 \\
(68,5 \%)\end{array}$ & $\begin{array}{c}7 \\
(7,9 \%)\end{array}$ \\
\hline & \multicolumn{6}{|l|}{ Mereferensikan pada orang lain } \\
\hline 5 & $\begin{array}{l}\text { Konsumen merekomendasikan } \\
\text { jasa Indomaret Bagus Kuning } \\
\text { Plaju pada orang lain. }\end{array}$ & $\begin{array}{c}0 \\
(0 \%)\end{array}$ & $\begin{array}{c}1 \\
(1,1 \%)\end{array}$ & $\begin{array}{c}19 \\
(21,3 \%)\end{array}$ & $\begin{array}{c}54 \\
(60,7 \%)\end{array}$ & $\begin{array}{c}15 \\
(16,9 \%)\end{array}$ \\
\hline 6 & $\begin{array}{l}\text { Konsumen menyampaikan hal-hal } \\
\text { positif pada orang lain. }\end{array}$ & $\begin{array}{c}0 \\
(0 \%) \\
\end{array}$ & $\begin{array}{c}5 \\
(5,6 \%) \\
\end{array}$ & $\begin{array}{c}17 \\
(1010 / 1\end{array}$ & $\begin{array}{c}53 \\
(59,6 \%) \\
\end{array}$ & $\begin{array}{c}14 \\
(15,7 \%) \\
\end{array}$ \\
\hline \multirow[t]{2}{*}{7} & $\begin{array}{l}\text { Kekebalan pada produk } \\
\text { pesaing }\end{array}$ & \multirow{2}{*}{$\begin{array}{c}0 \\
(0 \%)\end{array}$} & \multirow{2}{*}{$\begin{array}{c}8 \\
(9 \%)\end{array}$} & \multirow{2}{*}{$\begin{array}{c}52 \\
(58,4 \%)\end{array}$} & \multirow{2}{*}{$\begin{array}{c}19 \\
(21,3 \%)\end{array}$} & \multirow{2}{*}{$\begin{array}{c}10 \\
(11,2 \%)\end{array}$} \\
\hline & $\begin{array}{l}\text { Konsumen tidak tertarik } \\
\text { menggunakan jasa lain selain } \\
\text { yang pernah digunakan. }\end{array}$ & & & & & \\
\hline 8 & $\begin{array}{l}\text { Konsumen percaya menggunakan } \\
\text { jasa Indomaret Bagus Kuning } \\
\text { Plaju karena harganya lebih } \\
\text { murah dari lain. }\end{array}$ & $\begin{array}{c}0 \\
(0 \%)\end{array}$ & $\begin{array}{c}13 \\
(14,6 \%)\end{array}$ & $\begin{array}{c}48 \\
(53,9 \%)\end{array}$ & $\begin{array}{c}26 \\
(29,2 \%)\end{array}$ & $\begin{array}{c}2 \\
(2,2 \%)\end{array}$ \\
\hline
\end{tabular}

Tabel 14 Hasil Uji Normalitas DataOne-Sample Kolmogorov-Smirnov Test

\begin{tabular}{|c|c|c|c|c|c|}
\hline & & $\begin{array}{l}\text { Pelayanan } \\
\text { (X1) }\end{array}$ & $\begin{array}{c}\text { Harga } \\
(\mathrm{X} 2)\end{array}$ & $\begin{array}{c}\text { Kepuasan } \\
\text { Konsumen } \\
(Y)\end{array}$ & $\begin{array}{c}\text { Loyalitas } \\
\text { Konsumen } \\
(Z)\end{array}$ \\
\hline \multicolumn{2}{|l|}{$\bar{N}$} & 90 & 90 & 90 & 90 \\
\hline \multirow{2}{*}{$\begin{array}{l}\text { Normal } \\
\text { Parameters }{ }^{a, b}\end{array}$} & Mean & 2.8466 & 2.7957 & 2.4066 & 3.0191 \\
\hline & $\begin{array}{l}\text { Std. } \\
\text { Deviation }\end{array}$ & 0.52439 & 0.52029 & 0.50048 & 0.49685 \\
\hline \multirow{3}{*}{$\begin{array}{l}\text { Most Extreme } \\
\text { Differences }\end{array}$} & Absolute & 0.106 & 0.074 & 0.056 & 0.052 \\
\hline & Positive & 0.106 & 0.074 & 0.056 & 0.052 \\
\hline & Negative & -0.060 & -0.061 & -0.036 & -0.042 \\
\hline \multicolumn{2}{|c|}{ Kolmogorov-Smirnov Z } & 1.001 & 0.694 & 0.527 & 0.494 \\
\hline \multicolumn{2}{|c|}{ Asymp. Sig. (2-tailed) } & 0.269 & 0.722 & 0.944 & 0.967 \\
\hline
\end{tabular}


Tabel 15 Hasil Analisis Jalur Persamaan Struktural I

\begin{tabular}{|l|r|r|r|c|c|}
\hline \multirow{2}{*}{ Model } & \multicolumn{2}{|c|}{$\begin{array}{c}\text { Unstandardized } \\
\text { Coefficients }\end{array}$} & \multicolumn{1}{c|}{$\begin{array}{c}\text { Standardized } \\
\text { Coefficients }\end{array}$} & Sig. \\
\cline { 2 - 5 } & \multicolumn{1}{|c|}{ B } & Std. Error & \multicolumn{1}{c|}{ Beta } & & \\
\hline \multirow{2}{*}{$\begin{array}{l}\text { (Constant) } \\
\text { Pelayanan }\end{array}$} & $-0,068$ & 0,282 & & $-0,241$ & 0,810 \\
Jasa (X1) & 0,527 & 0,074 & 0,552 & 7,081 & 0,000 \\
Harga (X2) & 0,348 & 0,075 & 0,362 & 4,643 & 0,000 \\
\hline
\end{tabular}

maka estimasi fungsi regresi diperoleh adalah :

$Y=B_{1} X_{1}+\beta_{2} X_{2}+e_{1}$

$Y=0,552+0,362+e_{1}$

Tabel 16 Hasil Analisis Jalur Persamaan Struktural II

\begin{tabular}{|c|c|c|c|c|c|}
\hline \multirow[t]{2}{*}{ Model } & \multicolumn{2}{|c|}{$\begin{array}{l}\text { Unstandardized } \\
\text { Coefficients }\end{array}$} & $\begin{array}{l}\text { Standardized } \\
\text { Coefficients }\end{array}$ & \multirow[t]{2}{*}{$\bar{t}$} & \multirow[t]{2}{*}{ Sig. } \\
\hline & $B$ & Std. Error & Beta & & \\
\hline (Const & 1.091 & .314 & & 3.472 & .001 \\
\hline Pelayanan (X1) & .425 & .104 & .449 & 4.079 & .000 \\
\hline Harga (X2) & .119 & .093 & .125 & 1.278 & .205 \\
\hline $\begin{array}{l}\text { Kepuasan } \\
\text { Konsumen (Z) }\end{array}$ & 159 & .120 & 161 & 1.329 & . 188 \\
\hline
\end{tabular}

maka estimasi fungsi regresi diperoleh adalah

$Z=\beta_{3} X_{1}+\beta_{4} X_{2}+\beta_{5} Y+e_{2}$

$Z=0,449+0,125+0,161+e_{2}$

Tabel 17 Hasil Uji Multikoliniaritas

\begin{tabular}{|c|c|c|c|}
\hline \multicolumn{4}{|c|}{ Coefficients $^{a}$} \\
\hline \multirow{2}{*}{\multicolumn{2}{|c|}{ Model }} & \multicolumn{2}{|c|}{ Collinearity Statistics } \\
\hline & & Tolerance & VIF \\
\hline & (Constant) & & \\
\hline & Pelayanan Jasa (X1) & .986 & 1.015 \\
\hline & Harga $(\times 2)$ & .986 & 1.015 \\
\hline
\end{tabular}

a. Dependent Variable: Kepuasan Konsumen (n) Scatterplot

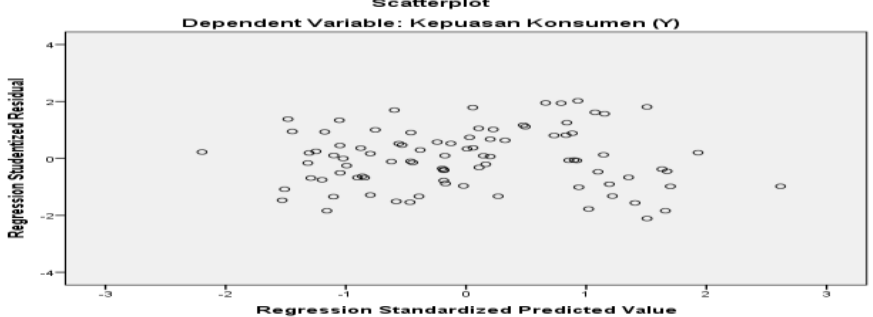

Gambar 2 Hasil Uji Heterokedastisitas 
Tabel 18 Hasil Uji Analisis Jalur Persamaan Struktural I

\begin{tabular}{|c|c|c|c|c|c|}
\hline \multirow[t]{2}{*}{ Model } & \multicolumn{2}{|c|}{$\begin{array}{l}\text { Unstandardized } \\
\text { Coefficients }\end{array}$} & $\begin{array}{l}\text { Standardized } \\
\text { Coefficients }\end{array}$ & \multirow[t]{2}{*}{$t$} & \multirow[t]{2}{*}{ Sig. } \\
\hline & $B$ & $\begin{array}{l}\text { Std. } \\
\text { Error }\end{array}$ & Beta & & \\
\hline (Constant) & -.068 & .282 & & -.241 & .810 \\
\hline $\begin{array}{l}\text { Pelayanan } \\
\text { Jasa }(\mathrm{X} 1)\end{array}$ & .527 & .074 & .552 & 7.081 & .000 \\
\hline Harga (X2) & .348 & .075 & .362 & 4.643 & .000 \\
\hline
\end{tabular}

a. Dependent Variable: Kepuasan Konsumen (Y)

Tabel 19 Hasil Uji Analisis Jalur Persamaan Struktural II

\begin{tabular}{|c|c|c|c|c|c|}
\hline \multirow[t]{2}{*}{ Model } & \multicolumn{2}{|c|}{$\begin{array}{l}\text { Unstandardized } \\
\text { Coefficients }\end{array}$} & $\begin{array}{l}\text { Standardized } \\
\text { Coefficients }\end{array}$ & \multirow[t]{2}{*}{$\mathrm{t}$} & \multirow[t]{2}{*}{ Sig. } \\
\hline & $B$ & $\begin{array}{l}\text { Std. } \\
\text { Error }\end{array}$ & Beta & & \\
\hline (Constant) & 1.091 & .314 & & 3.472 & .001 \\
\hline $\begin{array}{l}\text { Pelayanan } \\
\text { Jasa }(X 1)\end{array}$ & .425 & .104 & .449 & 4.079 & .000 \\
\hline Harga (X2) & .119 & .093 & .125 & 1.278 & .205 \\
\hline $\begin{array}{l}\text { Kepuasan } \\
\text { Konsumen (Y) }\end{array}$ & .159 & .120 & .161 & 1.329 & .188 \\
\hline
\end{tabular}

a. Dependent Variable: Loyalitas Konsumen (Z)

Tabel 20 Pengaruh Langsung dan Pengaruh Tidak Langsung antar variabel

\begin{tabular}{|l|c|c|c|}
\hline $\begin{array}{c}\text { Pengaruh } \\
\text { Variabel }\end{array}$ & $\begin{array}{c}\text { Pengaruh } \\
\text { Langsung }\end{array}$ & $\begin{array}{c}\text { Pengaruh tidak } \\
\text { langsung melalui } \\
\text { Kepuasan Konsumen }\end{array}$ & $\begin{array}{c}\text { Pengaruh } \\
\text { Total }\end{array}$ \\
\hline $\mathrm{X}_{1}$ ke $\mathrm{Y}$ & 0,552 & - & 0,552 \\
$\mathrm{X}_{1}$ ke Z & 0,449 & 0,088 & 0,537 \\
$\mathrm{Y}$ ke Z & 0,161 & - & 0,161 \\
$\mathrm{X}_{2}$ ke Y & 0,362 & - & 0,362 \\
$\mathrm{X}_{2}$ ke Z & 0,125 & 0,582 & 0,707 \\
\hline
\end{tabular}

Tabel 21 Hasil Uji Model Summary Kualitas pelayanan dan harga terhadap Kepuasan Konsumen

\begin{tabular}{|l|c|r|r|c|}
\hline Model & $R$ & $\begin{array}{c}\mathrm{R} \\
\text { Square }\end{array}$ & $\begin{array}{c}\text { Adjusted } \mathrm{R} \\
\text { Square }\end{array}$ & $\begin{array}{c}\text { Std. Error of the } \\
\text { Estimate }\end{array}$ \\
\hline 1 & $0.696^{\mathrm{a}}$ & 0.484 & 0.472 & 0.36355 \\
\hline
\end{tabular}

a. Predictors: (Constant), Harga (X2), Pelayanan (X1)

Tabel 22 Hasil Uji Determinasi Loyalitas Konsumen

\begin{tabular}{|l|c|r|r|c|}
\hline Model & $R$ & $\begin{array}{c}\mathrm{R} \\
\text { Square }\end{array}$ & $\begin{array}{c}\text { Adjusted } \mathrm{R} \\
\text { Square }\end{array}$ & $\begin{array}{c}\text { Std. Error of the } \\
\text { Estimate }\end{array}$ \\
\hline 1 & $0.600^{\mathrm{a}}$ & 0.359 & 0.337 & 0.40462 \\
\hline
\end{tabular}

a. Predictors: (Constant), Kepuasan Konsumen (Y), Harga (X2), Pelayanan (X1) 
KESIMPULAN DAN SARAN

\section{Kesimpulan}

1. Terdapat pengaruh kualitas pelayanan jasa terhadap kepuasan konsumen di Indomaret Bagus Kuning Plaju.

2. Terdapat pengaruh harga terhadap kepuasan konsumen di Indomaret Bagus Kuning Plaju.

3. Terdapat pengaruh kualitas pelayanan jasa terhadap loyalitas konsumen di Indomaret Bagus Kuning Plaju.

4. Tidak terdapat pengaruh harga terhadap loyalitas konsumen di Indomaret Bagus Kuning Plaju.

5. Tidak terdapat pengaruh kepuasan konsumen terhadap loyalitas konsumen di Indomaret Bagus Kuning Plaju.

\section{Saran}

1. Indomaret Bagus Kuning Plaju perlu berbenah diri dalam peningkatan kualitas pelayanan jasa bagi pelanggan.. Pegawai juga sebaiknya diberikan pendidikan/pelatihan khusus agar lebih profesional memberikan pelayanan terkait dengan jasa layanan.
2. Indomaret Bagus Kuning Plaju hendaknya memberikan promosi berupa diskon harga dan bonus untuk barang yang dijual. Pada saat pengunjung sepi, misalnya awal bulan ramadhan, sebaiknya memberikan potongan harga.

3. Sebaiknya kualitas pelayanan Indomaret Bagus Kuning Plaju ditingkatkan menjadi lebih baik untuk menciptakan rasa puas dan konsumen loyal untuk berbelanja kembali di Indomaret Bagus Kuning Plaju

4. Sebaiknya Indomaret Bagus Kuning mempertimbangkan dalam penetapan harga, harga yang tinggi jika diiringi kualitas pelayanan jasa dan produk yang diberikan maksimal dapat membuat konsumen loyal dan membuat konsumen senang untuk datang di Indomaret Bagus Kuning Plaju.

5. Kepuasan konsumen seharusnya dapat membentuk loyalitas konsumen, rasa loyal konsumen menggunakan jasa sebaiknya pihak Indomaret Bagus Kuning Plaju lebih gencar melakukan promosi produkproduk terbaru yang ditawarkan.

\section{DAFTAR PUSTAKA}

Alma, Bukhari. 2013. Manajemen Pemasaran dan Pemasaran Jasa. Cetakan ke-10. Bandung, Indonesia: Alfabeta

\section{Alqifari. 2016. Statistik Induktif, Jakarta: UPP STIM YKPN}

Dian, Utami, Novita. 2015. Pengaruh Kualitas Produk, Pelayanan, Harga dan Lokasi terhadap Loyalitas dengan Kepuasan Sebagai Variabel Intervening Pengunjung Rumah Makan Soto Lamongan "Cak Har" Surabaya. Jurnal Ilmu \& Riset Manajemen Volume 4 Nomor 5 Mei 2015.

Ghozali, 2014. Pengaruh Kualitas Pelayanan dan Harga terhadap Kepuasan Konsumen jasa pengiriman barang CV. Jaya Samudera Surabaya. Jurnal IImu dan Riset Manajemen Volume.3 Nomor.3 Diakses dari: https://ejournal.stiesia.ac.id/Jirm/article/viewfile/475/452 
Griffin, Jill. 2015. Customer Loyalty: Menumbuhkan dan Mempertahankan Kesetiaan Pelanggan. Jakarta. Indonesia: Erlangga.

Kotler, Philip Gary Amstrong, 2013. Dasar-dasar Pemasaran. Edisi 9 Jilid 1 dan 2. Jakarta. Indonesia: PT.Indeks Kelompok Gramedia

Nanda, Limakirisna. 2016. Manajemen Pemasaran Teori \& Aplikasi dalam Bisnis Edisi 2, Jakarta: Mita Wacana Mulia

Riduwan. 2012. Pengantar Statistik Pendidikan, Sosial, Ekonomi, Komunikasi dan Bisnis. (cet.7). Bandung, Indonesia: Alfabeta.

Sudaryono, 2016, Manajemen Pemasaran Teori Implementasi \& Implementasi, Yogyakarta: Andi Offset

Sugiyono. (2017). Statistik untuk Penelitian. (cet.20). Bandung, Indonesia: Alfa Beta.

Sunyoto, 2013, Perilaku Konsumen Teori dan Penerapan Dalam Pemasaran, Jakarta: Penerbit PT. Ghalia Indonesia

Supranti, J 2016, Statistik Teori \& Aplikasi Edisi 8 Jilid 1\&2, Jakarta: Erlangga

Supranto. M.A. 2012. Pengukuran Tingkat Kepuasan PelangganUntuk Menaikkan Pangsa Pasar. Jakarta: Rineka Cipta.

Supriyanto, RW, 2015, Manajemen Pemasaran, Bogor, In Media

Rangkuti, Freddy. 2016. Riset Pemasaran. Jakarta. Indonesia: Gramedia Pustaka Utama

Riadi, Edi, 2016, Statistik Penelitian Analisis Manual Dan IBM SPSS, Yogyakarta: Andi

Riduwan, 2012, Belajar Mudah Penelitian Untuk Guru-Karyawan dan Peneli Pemula, Bandung: Alfabeta

Tjiptono, Fandy. 2016. Pemasaran Esensi \& Aplikasi. Yogyakarta. Indonesia: Andy

Walton. 2011. The Brave New World of Neuromarketing is Here B \& I. Australia.

Zeithalm, Valarie A \& Bitner, Mary Jo. 2011. Consumer Behavior. Edisi ke-8. Pearson Prentice Hall. 